Jurnal Keperawatan Silampari

Volume 5, Nomor 1, Desember 2021

e-ISSN: 2581-1975

p-ISSN: 2597-7482

DOI: https://doi.org/10.31539/jks.v5i1.3027

IDMEKpE

\title{
KUALITAS HIDUP DAN KESIAPSIAGAAN BENCANA GEMPA BUMI PADA MASYARAKAT PESISIR PANTAI PANJANG KELURAHAN TELUK SEPANG
}

\author{
Nurrobikha $^{1}$, Novrikasari $^{2}$, Yuanita Windusari ${ }^{3}$ \\ Universitas Sriwijaya ${ }^{1,2,3}$ \\ novrikasari@fkm.unsri.ac.id ${ }^{2}$
}

\begin{abstract}
ABSTRAK
Penelitian ini bertujuan untuk menganalisis kualitas hidup dan kesiapsiagaan bencana gempa bumi Masyarakat di wilayah Pesisir Pantai Panjang Kelurahan Teluk Sepang Bengkulu. Metode penelitian ini menggunakan penelitian observasional analitik dengan desain cross-sectional. Hasil penelitian menunjukkan bahwa 82 orang (82\%) memiliki kualitas hidup yang baik dan 18 orang (18\%) diantaranya memiliki kualitas hidup yang kurang baik, dan sebagian besar responden 68 orang (68\%) memiliki kesiapsiagaan yang baik, dan 32 orang (32\%) memiliki kesiasiagaan yang kurang baik. Hasil analisis diperoleh hasil yang signifikan kualitas hidup dengan kesiapsiagaan $(p=0,001$, OR 7,28). Hasil uji multivariat menunjukkan bahwa kualitas hidup merupakan faktor paling dominan berhubungan dengan kesiapsiagaan bencana alam gempa bumi. Simpulan, terdapat hubungan yang bermakna antara kualitas hidup terhadap kesiapsiagaan bencana alam gempa bumi pada masyarakat di wilayah Pesisir Pantai Panjang Kelurahan Teluk Sepang Bengkulu
\end{abstract}

Kata Kunci: Kesiapsiagaan Bencana Gempa Bumi, Kualitas Hidup

\section{ABSTRACT}

This study aims to analyze the community's quality of life and earthquake disaster preparedness in the Long Coastal Coast area, Teluk Sepang Village, Bengkulu. This research method uses an analytical observational study with a cross-sectional design. The results showed that 82 people (82\%) had a good quality of life and 18 people (18\%) of them had a poor quality of life, and most of the respondents, 68 people (68\%), had good preparedness, and 32 people (32\%) had poor preparedness. The analysis results obtained significant results of quality of life with readiness ( $p=0.001$, OR 7.28). The multivariate test results showed that the quality of life was the most dominant factor associated with earthquake preparedness. In conclusion, there is a significant relationship between quality of life and preparedness for natural earthquake disasters in the Long Coastal area, Teluk Sepang Village, Bengkulu.

Keywords: Earthquake Disaster Preparedness, Quality of Life 


\section{PENDAHULUAN}

Indonesia secara geografis dan klimatologi mempunyai tantangan untuk melindungi dan memperkuat masyarakat dari ancaman risiko bencana. Pergerakan tiga lempeng tektonik besar, yaitu lempeng Indo Australia di bagian selatan, Lempeng Samudera Pasifik di sebelah timur, lempeng Eurasia di sebelah utara (dimana disebagian besar wilayah Indonesia) dan disertai daerah aliran sungai (5.590 DAS) mengakibatkan risiko bencana geologi seperti gempa bumi, tsunami, letusan gunung api (129 gunung api aktif) maupun gerakan tanah/ longsor (Setyaningrum \& Setyorini, 2020; BNPB, 2018).

Daya rusak yang ditimbulkan fenomena alam tersebut bahkan bisa menghancurkan sebagian peradaban manusia. Untuk itu penanggulangannya dalam rangka mencegah dan mengurangi dampak bencana alam haruslah meliputi deteksi dini fenomena alam penyebab bencana sampai dengan management saat bencana melanda. Setiap bencana, baik bencana alam maupun bencana akibat kelalaian manusia telah meninggalkan duka, trauma, kesan, dan sejarah, baik terhadap korban maupun pihak lain yang menyaksikan atau mengetahui kejadian bencana tersebut. Catatan sejarah bencana diperlukan sebagai pengingat, pelajaran sekaligus peringatan bagi umat manusia. Bencana alam yang terjadi di Indonesia dalam kurun waktu 10 tahun belakangan ini menunjukkan perningkatan frekuensi. Bencana alam tersebut telah memakan banyak korban, baik meninggal dunia maupun luka serta mengakibatkan banyak warga yang kehilangan tempat tinggal dan harta bendanya.

Bencana alam itu seringkali terjadi akibat aktivitas manusia yang mengganggu kelestarian dan keseimbangan alam seperti deforestasi yang tidak terkendali, pembakaran hutan, tata kelola sampah yang buruk, dan lain sebagainya. Oleh karena itu, sekarang adalah saatnya untuk mulai memperhatikan keseimbangan alam sebagai salah satu upaya pencegahan bencana alam yang mungkin dapat terjadi jika keseimbangan alam terganggu oleh ulah manusia. Selain itu, untuk bencana alam yang sangat sulit diprediksi karena merupakan rahasia besar-Nya, sehingga kita tidak dapat mencegahnya, hendaknya menyadarkan manusia dengan meningkatkan kehati-hatian dan kesiapsiagaan, khususnya untuk yang bertempat tinggal di daerah yang rawan dengan tidak lupa memohon pertolongan-Nya (BPBD, 2020).

Gempa bumi merupakan bencana alam yang cukup sering terjadi di Indonesia. Dalam kurun waktu 10 tahun terakhir (2009-2019) gempa bumi telah terjadi sebanyak 216 kali dengan jumlah korban hilang dan meninggal dunia sebanyak 637 jiwa, 8.687 korban luka-luka, 459.855 pengungsi, 602.223 unit rumah warga rusak serta 131 fasilitas umum yang juga mengalami kerusakan (Hadi et al., 2019; BNPB, 2018).

Daerah yang termasuk rawan gempa di Indonesia antara lain; Aceh, Sumatera Utara (Simeulue), Sumatera Barat - Jambi, Bengkulu, Lampung, Banten Pandeglang, Jawa Barat, Bantar Kawung, Yogyakarta, Lasem, Jawa Timur, Bali, NTB, NTT, Kepulauan Aru, Sulawesi Selatan, Sulawesi Tenggara, Sulawesi Tengah, Sulawesi Utara, Sangir Talaud, Maluku Utara, Maluku Selatan, Kepala Burung, Papua Utara, Jayapura, Nabire, Wamena, dan Kalimantan (BPDB, 2020).

Provinsi Bengkulu terletak di kawasan Pesisir Pantai Barat Pulau Sumatera. Provinsi ini memiliki garis pantai $525006 \mathrm{~m}$ yang langsung berhubungan dengan Samudera Hindia. Secara geografis Provinsi Bengkulu terletak diantara 02 $16^{\prime}$ $03^{\circ} 31^{\prime} \mathrm{LS}$ dan $101^{\circ} 01^{\prime}-103^{\circ} 41^{\prime} \mathrm{BT}$. Wilayahnya terdiri dari 9 kabupaten, 1 kota, 126 kecamatan, 148 desa, dan 1.294 desa. Dengan luas 19.919,33 km2 . Provinsi Bengkulu dibagi menjadi tiga wilayah fisiografis, yaitu dataran rendah di sepanjang pantai barat, bukit-bukit di wilayah tengah, dan pegunungan di wilayah timur yang berbatasan dengan Jambi dan Sumatera Selatan. Bengkulu juga terletak di zona tabrakan aktif dua 
lempeng tektonik, yaitu Lempeng Indo-Australia dan Lempeng Eurasia. Merujuk pada kondisi tersebut, Bengkulu merupakan provinsi rawan gempa bencana, gelombang pasang, banjir, dan tanah longsor (BPBD, 2020).

Gempa bumi berkekuatan 8 skala richter terjadi pada tanggal 4 Juni 2020 menimbulkan bencana paling besar di Bengkulu. Kurun waktu Januari hingga Febriari 2020, Badan Meteorologi Klimatologi dan Geofisika (BMKG) stasiun Geofisika Kepahiang mencatat telah terjadi 168 kali gempa yang mengguncang Propinsi Bengkulu. Tujuh tahun setelah gempa itu, tepatnya pada tanggal 12 Sepember 2007, gempa berkekuatan 7,9 skala Richter mewaskan 15 orang dan merusak 67.191 bangunan. September 2018 terjadi 5 kejadian gempa di wilayah Bengkulu dan sekitarnya, gempa terbesar terjadi pada 12 September 2018 dengan skala 5,3 richter, dengan lokasi 127 km Barat Daya Manna, Kabupaten Bengkulu Selatan (BMKG, 2020).

Berdasarkan penjelasan di atas, diketahui bahwa Teluk Sepang merupakan salah satu daerah di Propinsi Bengkulu yang juga beresiko menghadapi gempa dan tsunami karena terletak di pesisir pantai. Fenomena yang terjadi tidak membuat warga setempat untuk melakukan migrasi ke daerah lain di karenakan penduduk setempat merupakan penduduk asli yang telah lama menetap di kawasan tersebut, dan sebagaian besar masyarakat bekerja sebagai nelayan dan anak buah kapal, hal tersebut membuat mereka tidak bersedia untuk bermigrasi ke daerah yang lebih aman.

Meski telah sering menghadapai bencana dan pihak pemerintah telah memberi edukasi mengenai kesiapsiagaan bencana serta membangun selter, namun masyarakat Teluk Sepang belum sepenuhnya memahami dan memanfaatkan fasilitas yang telah ada, sehingga setiap terjadi bencana gempa korban jiwa dan materi masih terus ada dalam jumlah yang cukup banyak.

Melakukan sebuah studi kualitas hidup korban gempa menunjukkan bahwa gempa menimbulkan dampak sosial dan psikologis pada seluruh komunitas sangat besar. Kurangnya prediktabilitas, pengingat kehancuran dan kebutuhan untuk pindah karena kehancuran rumah dapat mengakibatkan efek mulai dari keputusasaan hingga masalah kesehatan mental yang serius dengan memperburuk reaksi emosional yang terkait dengan trauma. Penelitian ini juga menggunakan Skor WHOQOL-BREF dalam mengukur kualitas hidup yang hasilnya menunjukkan bahwa kelompok usia yang lebih tua dan berpendidikan rendah memiliki skor yang cukup tinggi dalam skor QOL pasca trauma. Pada kategori usia muda dan menengah tingkat hubungan sosial cenderung menurun. Dari keseluruhan hasil penelitian disimpulkan bahwa gempa berdampak pada menurunnya kualitas hidup masyarakat korban gempa (Ardiani et al., 2019).

Rajendran et al., (2021) menyatakan bahwa setiap pekerja mengharapkan keselamatan di lingkungan tempat kerja. Setiap organisasi harus mengidentifikasi bahaya dan menentukan risiko yang terkait dengannya dan merancang fasilitas untuk mengurangi risiko tersebut. Teknologi memiliki potensi untuk memecahkan setiap masalah yang dihadapi masyarakat dibidang kesehatan dan keselamatan kerja dan berperan dalam mengurangi kecelakaan kerja.

Beberapa penelitian terkait yang telah diuraikan tersebut menunjukkan bahwa kualitas hidup memiliki hubungan terhadap kesiapsiagaan bencana. Selain mempersiapkan kualitas hidup masyarakat, pemerintah Kota Bengkulu berusaha untuk mempersiapkan lingkungan pemukiman yang disesuaikan dengan keadaan Teluk Sepang yang merupakan daerah rawan bencana, pemerintah Kota Bengkulu melakukan pembangunan jalur evakuasi pada akhir 2014 yang menghubungkan Kelurahan Teluk Sepang dengan 
Padang Serai, jalur evakuasi ini dibangun atas dukungan pemerintah pusat melalui Badan Nasional Penanggulangan Bencana (BNPB).

Berdasarkan fenomena yang telah dijelaskan di atas maka penulis merasa tertarik untuk melakukan penelitian guna mengetahui sejauh mana kualitas hidup masyarakat di Teluk Sepang yang kita ketahui merupakan daerah rawan gempa, apakah edukasi yang diberikan, fasilitas dan prasarana yang telah disediakan pemerintah, tepat sasaran dan tepat guna sehingga masyarakat telah memiliki kesiapsiagaan mengahadapi bencana.

Penelitian ini bertujuan untuk menganalisis hubungan kualitas hidup terhadap kesiapsiagaan bencana gempa bumi pada masyarakat Pesisir Pantai Panjang Kelurahan Teluk Sepang Bengkulu. Dari penelitian ini kita ketahui penemuan baru untuk bisa dilanjutkan di masa mendatang, lebih dari 85 penduduk kelurahan teluk sepang Bengkulu menggunakan air galon isi ulang dan PDAM untuk dikonsumsi, bahkan ada yang mengkonsumsi air hujan. Air yang berasal dari sumur gali ataupun sumur bor, jernih tetapi sedikit berasa jadi masyarakat Teluk Sepang tidak nyaman dan tidak terbiasa meminumnya. Hal ini tentu lambat laun akan dapat mempengaruhi kesehatan masyarakat Teluk Sepang bila ada yang memaksakan diri untuk tetap meminum air dari sumur gali. Tetapi Alhamdulillah air tersebut digunakan untuk kebutuhan MCK dan sangat sedikit sekali yang menggunakan untuk dijadikan air minum atau kebutuhan memasak. Hal ini berhubungan dengan kualitas hidup, karena kesehatan juga ditentukan dari layak tidaknya konsumsi air minum kita sehari hari. Mungkin mendatang bisa diteliti kembali kualitas air di daerah ini.

\section{METODE PENELITIAN}

Jenis penelitian ini adalah observasional analitik dengan desain cross-sectional. Penelitian ini dilakukan di Teluk Sepang Bengkulu pada bulan Oktober tahun 2021. Sampel penelitian ini adalah 100 orang kepala keluarga yang berdomisili di Kelurahan Teluk Sepang Kota Bengkulu dengan menggunakan teknik proportional random sampling, yakni pengambilan sampel berdasarkan proporsi KK setiap RT di Kelurahan Teluk Sepang. Analisis data, dilakukan dengan menggunakan analisis univariat, bivariat, dan multivariat.

\section{HASIL PENELITIAN}

\section{Analisis Univariat}

Tabel. 1

Distribusi Frekuensi Karakteristik Kepala Keluarga

\begin{tabular}{lcc}
\hline \multicolumn{1}{c}{ Variabel } & $\mathrm{N}$ & $\%$ \\
\hline 1. Usia & & \\
a. 25 -40 Tahun & 34 & 34 \\
b. 41-65 Tahun & 66 & 66 \\
\hline 2. Pendidikan & & \\
$\quad$ a. Rendah & 56 & 56 \\
b. Tinggi & 44 & 44 \\
\hline 3. Pekerjaan & & \\
a. ABK & 47 & 47 \\
b. Petani & 18 & 18 \\
c. Pedagang & 16 & 16 \\
d. Buruh & 9 & 9 \\
e. ASN & 4 & 4 \\
f. Karyawan Swasta & 6 & 6 \\
\hline
\end{tabular}




\begin{tabular}{llcc}
\hline 4. Kualitas Hidup & & \\
a. Baik & 82 & 82 \\
b. Kurang baik & 18 & 18 \\
\hline 5. Lingkungan Pemukiman & 78 & 78 \\
& a. Baik & 22 & 22 \\
b. Kurang baik & & \\
\hline 6. Kesiapsiagaan & 68 & 68 \\
a. Baik & 32 & 32 \\
b. Kurang baik. & 100 & 100 \\
\hline Total
\end{tabular}

Berdasarkan pada tabel 1 diketahui dari 100 orang responden didapati 82 orang $(82 \%)$ memiliki kualitas hidup yang baik dan 18 orang (18\%) diantaranya memiliki kualitas hidup yang kurang baik, dan sebagian besar responden 68 orang (68\%) memiliki kesiapsiagaan yang baik, dan 32 orang (32\%) memiliki kesiasiagaan yang kurang baik.

\section{Analisis Bivariat \\ Hubungan Kualitas Hidup dengan Kesiapsiagaan Bencana Gempa Bumi pada Masyarakat Pesisir Pantai Panjang Kelurahan Teluk Sepang Bengkulu}

Tabel. 2

Hubungan Kualitas Hidup dengan Kesiapsiagaan

Bencana Gempa Bumi

\begin{tabular}{|c|c|c|c|c|c|c|c|c|c|}
\hline \multirow{3}{*}{ No } & \multirow{3}{*}{ Kualitas hidup } & \multicolumn{4}{|c|}{ Kesiapsiagaan } & \multirow{3}{*}{$\mathrm{N}$} & \multirow{3}{*}{$\%$} & \multirow{3}{*}{ p. value } & \multirow{3}{*}{ OR } \\
\hline & & \multicolumn{2}{|c|}{ Baik } & \multicolumn{2}{|c|}{ Kurang baik } & & & & \\
\hline & & $\mathrm{f}$ & $\%$ & $\mathrm{f}$ & $\%$ & & & & \\
\hline 1. & \multirow{2}{*}{$\begin{array}{l}\text { Baik } \\
\text { Kurang Baik }\end{array}$} & 65 & 79,2 & 17 & 20,8 & 82 & 100 & \multirow{3}{*}{0,001} & \multirow{3}{*}{7,280} \\
\hline 2. & & 3 & 16,6 & 15 & 83,4 & 18 & 100 & & \\
\hline \multicolumn{2}{|r|}{ Total } & 68 & & 32 & & 100 & & & \\
\hline
\end{tabular}

Berdasarkan tabel 2 diperoleh hasil bahwa dari 82 responden yang memiliki kualitas hidup baik terdapat 65 orang $(79,2 \%)$ dengan kesiapsiagaan baik dan 17 orang $(20,8 \%)$ dengan kesiapsiagaan kurang baik, sedangkan dari 18 responden yang memiliki kualitas hidup kurang baik terdapat 3 orang $(16,6 \%)$ dengan kesiapsiagaan baik dan 15 orang $(83,4 \%)$ dengan kesiapsiagaan kurang baik. Hasil analisis diperoleh hasil yang signifikan kualitas hidup dengan kesiapsiagaan ( $p=0,001$, OR 7,28), sehingga ada hubungan antara kualitas hidup dengan kesiapsiagaan dengan resiko7,28 responden yang memiliki kualitas hidup baik akan memiliki kesiapsiagaan yang baik.

\section{Analisis Multivariat}

Tabel. 3

Analisis Multivariat Metode Regresi Logistik

\begin{tabular}{lccccc}
\hline \multicolumn{1}{c}{ Variabel independen } & $\mathrm{B}$ & $p$ & OR & \multicolumn{2}{c}{$95 \%$ CI } \\
\hline Usia & 2,453 & 0,032 & 7,286 & 2,453 & 1.6231 \\
Pendidikan & 2,071 & 0,023 & 7,932 & 2,071 & 1.0710 \\
Pekerjaan & 2,253 & 0,014 & 7,861 & 2,453 & 1.4328 \\
Kualitas hidup & 18,585 & 0,001 & 18,000 & 18,585 & 8.3210 \\
Lingkungan pemukiman & 21,336 & 0,012 & 16,845 & 9,336 & 6.3241 \\
\hline Constant & 1.728 & 2.714 & 3.045 & & \\
\hline
\end{tabular}


Pada tabel regresi logistik biner menunjukkan variabel yang paling berpengaruh terhadap kesiapsiagaan yaitu kualitas hidup 8,321 kali responden yang memiliki kualitas hidup baik akan memiliki kesiapsiagaan yang baik.

\section{PEMBAHASAN}

Berdasarkan pada tabel 1 diperoleh hasil sebagian besar responden kualitas hidup responden 82 orang $(82 \%)$ baik. Hal ini dapat dilihat dari jawaban responden yang mengatakan bahwa dalam 2 minggu terakhir rasa sakit fisik sama sekali tidak menghalangi untuk beraktivitas, jarang membutuhkan terapi medis untuk menjalankan aktivitas sehari-hari sehingga sangat menikmati hidup dan merasa hidup lebih bermakna. Selain itu, responden juga mengatakan bahwa memiliki cukup uang untuk memenuhi kebutuhan sehari-hari, memiliki kesempatan untuk rekreasi sehingga merasa puas dalam tidur dan dalam menjalin hubungan sosial sehari-hari. Kepuasan terhadap tempat tinggal, transportasi dan pelayanan kesehatan juga dirasakan oleh responden. Responden juga mengatakan jarang merasa kesepian, putus asa, cemas ataupun depresi.

Berdasarkan kesiapsiagaan bencana diketahui bahwa 68 orang $(68 \%)$ dengan kategori baik. Hal ini dapat dilihat dari jawaban responden yang mengatakan bahwa ada pembagian tugas dalam tindakan penyelamatan apabila terjadi kondisi darurat, tersedia peta tempat jalur evakuasi keluarga dan tempat berkumpulnya keluarga apabila terjadi bencana gempa bumi, ada kerabat/keluarga yang menyediakan tempat pengungsian sementara apabila terjadi bencana gempa bumi. Selain itu, tersedia kotak P3K atau obat obatan penting untuk pertolongan pertama, ada alat komunikasi dan sudah memiliki nomor-nomor penting yang bisa dihubungi dalam keadaan darurat. Beberapa responden juga mengatakan pernah memperoleh informasi tentang kesiapsiagaan bencana dalam bentuk pelatihan dan penyuluhan (World Health Organization, 2018).

Kesiapsiagaan merupakan salah satu elemen penting didalam pengelolaan bencana alam. Termasuk didalamnya dalam menghadapi bencana alam gempa bumi. setiap komunitas hendaknya memiliki kesiapsiagaan yang tinggi terhadap ancaman resiko bencana. Terutama di negara kita yang notabene adalah kawasan yang memiliki ancaman potensi bencana gempa bumi yang tinggi. Kesiapsiagaan mutlak diperlukan, mengingat dalam penanggulangan bencana telah terjadi pergeseran paradigma dari fatalistic responsive yang berorientasi pada respon kedaruatan akibat bencana menuju kepada proactive preparedness yaitu penanggulangan bencana yang dilakukan sejak dini melalui kesiapsiagaan hingga tahap pemulihan sosial. Paradigma ini menuntut pemerintah dan masyarakat secara bersama-sama melaksanakan upaya pengurangan resiko (Anam et al., 2018; Raja et al., 2017).

Peristiwa bencana yang pernah dialami oleh seseorang bisa menjadi stimulus yang memberikan pengalaman dan mempengaruhi tingkat kesiapan seseorang dalam menghadapi bencana. Bencana yang diterima seseorang akan memberikan proses pembelajaran yang bermanfaat bagi individu dalam membentuk perilaku kesiapan dalam menghadapi bencana berikutnya. Proses pembelajaran tersebut tercermin dari adanya langkah persiapan yang dilakukan masyarakat, sehingga dapat meminimalisir korban dan dampak psikologis dari bencana. Perilaku kesiapan ini juga didukung oleh kemampuan individu untuk bangkit kembali dari peristiwa trauma yang pernah terjadi. Kemampuan inilah yang kemudian disebut dengan resiliensi. Semua orang mempunyai risiko terhadap potensi bencana, sehingga penanganan bencana merupakan urusan semua pihak (everybody's business). Oleh sebab itu, perlu dilakukan berbagi peran dan tanggung jawab (shared responsibility) dalam peningkatan kesiapsiagaan di semua 
tingkatan, baik anak, remaja, dan dewasa. Seperti yang telah dilakukan di Jepang, untuk menumbuhkan kesadaran kesiapsiagaan bencana. Dalam menghadapi bencana alam ada istilah kelompok rentan. Kelompok rentan adalah suatu keadaan atau kondisi lingkungan dari suatu komunitas atau masyarakat yang mengarah atau menyebabkan ketidakmampuan dalam menghadapi ancaman bencana (Michiko, 2020).

Kerentanan bagi perempuan menjadi ganda karena peran kodrat, seperti haid, hamil, melahirkan dan memberikan ASI yang jika tidak diprioritaskan akan berpotensi menyebabkan ketidakadilan gender, dan juga peran gender yang diharapkan oleh masyarakat kepada perempuan membuat mereka kehilangan akses, partisipasi, kontrol terhadap pengambilan keputusan dan tidak mendapat manfaat dari penyelenggaraan penanggulangan bencana (Ardiani et al., 2019).

Tingkat kerentanan dapat ditinjau dari empat aspek, yaitu; kerentanan fisik (infrastruktur), menggambarkan suatu kondisi fisik yang rawan terhadap bahaya (hazard) tertentu. Kondisi kerentanan ini dapat dilihat dari berbagai indikator, antara lain; persentase kawasan terbangun, kepadatan bangunan, persentase bangunan konstruksi darurat, jaringan listrik, rasio panjang jalan, jaringan telekomunikasi, lingkungan pertanian, hutan, dan lain-lain. Kerentanan sosial kependudukan menggambarkan kondisi tingkat kerapuhan sosial dalam menghadapi bahaya. Pada kondisi sosial yang rentan, maka jika bencana terjadi dapat dipastikan akan menimbulkan dampak kerugian yang besar. Beberapa indikator kerentanan sosial, antara lain kepadatan penduduk, laju pertumbuhan penduduk, persentase penduduk usia tua-balita dan penduduk perempuan, kelembagaan masyarakat, tingkat pendidikan, dan lain-lain. Kerentanan ekonomi menggambarkan suatu kondisi tingkat kerapuhan ekonomi dalam menghadapi ancaman bahaya. Beberapa indikator kerentanan ekonomi diantaranya, mata pencaharian masyarakat, tingkat pengangguran, kesenjangan tingkat kesejahteraan. Kerentanan lingkungan menggambarkan tingkat ketersediaan/kelangkaan sumber daya (lahan, air, udara) serta kerusakan lingkungan yang terjadi (Jacob \& Sandjaya , 2018).

Berdasarkan tabel bivariat diperoleh hasil bahwa dari 82 responden yang memiliki kualitas hidup baik terdapat 65 orang $(79,2 \%)$ dengan kesiapsiagaan baik dan 17 orang $(20,8 \%)$ dengan kesiapsiagaan kurang baik, sedangkan dari 18 responden yang memiliki kualitas hidup kurang baik terdapat 3 orang $(16,6 \%)$ dengan kesiapsiagaan baik dan 15 orang $(83,4 \%)$ dengan kesiapsiagaan kurang baik. Hasil analisis diperoleh hasil yang signifikan kualitas hidup dengan kesiapsiagaan $(p=0,001$, OR 7,28) dengan artian ada hubungan antara kualitas hidup dengan kesiapsiagaan dengan resiko7,28 responden yang memiliki kualitas hidup baik akan memiliki kesiapsiagaan yang baik.

Rajendran et al., (2021) menyatakan bahwa setiap pekerja mengharapkan keselamatan di lingkungan tempat kerja. Setiap organisasi harus mengidentifikasi bahaya dan menentukan risiko yang terkait dengannya dan merancang fasilitas untuk mengurangi risiko tersebut. Teknologi memiliki potensi untuk memecahkan setiap masalah yang dihadapi masyarakat. di bidang kesehatan dan keselamatan kerja dan berperan dalam mengurangi kecelakaan kerja.

\section{SIMPULAN}

Terdapat hubungan yang signifikan antara kualitas hidup, dengan kesiapsiagaan menghadapi bencana gempa bumi pada masyarakat Teluk Sepang Kota Bengkulu. 


\section{SARAN}

Perlu ditingkatkannya upaya promosi kesehatan terkait kesehatan dan keselamatan kerja dan pelatihan kesiapsiagaan menghadapi bencana serta meningkatan kualitas sarana dan prasarana bagi masyarakat Teluk Sepang untuk mengurangi resiko kerugian dan korban pada bencana yang mungkin akan datang di masa mendatang.

\section{DAFTAR PUSTAKA}

Anam, K., Mutholib, A., Setiyawan, F., Andini, B, A., \& Sefniwati, S. (2018). Kesiapan Institusi Lokal dalam Menghadapi Bencana Tsunami: Studi Kasus Kelurahan Air Manis dan Kelurahan Purus, Kota Padang. Jurnal Wilayah dan Lingkungan, 6(1), 15-29. DOI: 10.14710/jwl.6.1.15-29

Ardiani, H., Lismayanti, L., \& Rosnawaty, R. (2019). Faktor-Faktor yang Berhubungan dengan Kualitas Hidup Lansia di Kelurahan Mugarsari Kecamatan Tamansari Kota Tasikmalaya Tahun 2014. Healthcare Nursing Journal, 1(1), pp. 42-50. https://journal.umtas.ac.id/index.php/healtcare/article/view/301

BMKG. (2020). Stasiun Geofisika Kepahiang. https://www.bmkg.go.id/profil/stasiunupt.bmkg? id =74

BNPB. (2018). Panduan Kesiapsiagaan Bencana untuk Keluarga. Retrieved from https://siaga.bnpb.go.id/hkb/pocontent/uploads/documents/Buku_Pedoman_Kesia psiagaan_Keluarga_FA_A5.pdf

BPBD. (2020). Badan Penanggulangan Bencana Daerah (BPBD), Http://Bpbd.Semarangkota.Go.Id, (19). Available at: https://sakip.bengkulukota.go.id/dok/1603268481_LKJIP BPBD Kota Bengkulu 2019 sudah final - Copy.pdf

Hadi, H., Agustina, S., \& Subhani, A. (2019). Penguatan Kesiapsiagaan Stakeholder dalam Pengurangan Risiko Bencana Gempabumi. Jurnal Geodika, 3(1), 30-40. https://e-journal.hamzanwadi.ac.id/index.php/gdk/article/view/1476/0

Jacob, D. E., \& Sandjaya, S. (2018). Faktor Faktor yang Mempengaruhi Kualitas Hidup Masyarakat Karubaga District Sub District Tolikara Propinsi Papua. Jurnal Nasional Ilmu Kesehatan (JNIK), $1(69), \quad 16$. https://journal.unhas.ac.id/index.php/jnik/article/view/4281

Michiko, S. (2020). Keselamatan Kerja dalam Pelayanan Penanggulangan Bencana di Badan Penanggulangan Bencana Daerah Kab Sidoarjo. DIA: Jurnal Ilmiah Administrasi Publik, 16(2), 40. DOI: 10.30996/dia.v16i2.1922

Raja, Z, D, G., Hendrawan, H., \& Sunardi. S. (2017). Upaya Penanggulangan Risiko dan Kesiapsiagaan Masyarakat Terhadap Anacaman Bencana Tanah Longsor. Jurnal Lingkungan dan Bencana Geologi, 8(2), 103-116. http://jlbg.geologi.esdm.go.id/index.php/jlbg/article/view/176

Rajendran, S., Giridhar, S., Chaudhari, S., \& Gupta, P. K. (2021). Technological Advancements in Occupational Health and Safety. Measurement: Sensors. Elsevier Ltd, 15(4), 100045. doi: 10.1016/j.measen.2021.100045

Setyaningrum, N., \& Setyorini, A. (2020). Tingkat Kesiapsiagaan Kepala Keluarga dalam Menghadapi Bencana Gempa Bumi di Kecamatan Pleret dan Piyungan Kabupaten Bantul. Jurnal Kesehatan Al-Irsyad, 13(1), 84-92. https://ejurnal.stikesalirsyadclp.ac.id/index.php/jka/article/view/61

World Health Organization (2018) Occupational Safety and Health in Public Health Emergencies:, Ginebra, Suiza: World Health Organization. Available at: https://apps.who.int/iris/bitstream/handle/10665/275385/9789241514347-eng.pdf 